
\title{
is Research Suare \\ Ecological and Floristic Study of Hirmi Forest, Tigray Region, Northern Ethiopia
}

Mehari Girmay ( $\nabla$ meharigrm@gmail.com )

Addis Ababa University

Tamrat Bekele

Addis Ababa University

Sebsebe Demissew

Addis Ababa University

Ermias Lulekal

Addis Ababa University

\section{Original Article}

Keywords: Diversity, Dryland, Ecological Data, Hirmi forest, Plant Communities

Posted Date: July 24th, 2020

DOI: https://doi.org/10.21203/rs.3.rs-29950/v2

License: (c) (i) This work is licensed under a Creative Commons Attribution 4.0 International License.

Read Full License 
The authors have withdrawn this preprint from Research Square 